\title{
Pusat Kebudayaan Sebagai Wadah Seni Pertunjukan Dengan Pendekatan Genius Loci Di Kotagede
}

\author{
Rud Yoneko Tunggadewi, Hardiyati, Kusumaningdyah Nurul Handayani \\ Program Studi Arsitektur \\ Universitas Sebelas Maret Surakarta \\ Email : rudyoneko@gmail.com
}

\begin{abstract}
Sustainability of cultural heritage in Yogyakarta continues to face barriers, those are partly due to the result of natural disasters, economic pressure, space requirements for modern activities and the lack of understanding and concern of the local community to the cultural heritage owned. Kotagede is one of Yogyakarta's cultural image-forming spot that still has diverse cultural heritage, which includes traditional house and performing art groups. Cultural Center presents as an effort of conservation, utilization, and development to maintain the sustainability of cultural heritage in Kotagede. The designing problems to solve are regarding with the concept of zoning and transforming Kotagede traditional house as a place of performing art activities, as well as with regard to the concept of circulation, transportation, nodes, and paths to connect them. Genius Loci is deployed to preserve the historical value, uniqueness, and authenticity owned by Kotagede. Genius Loci is the soul of a place that can be felt through identification and orientation towards the boundaries. As the object of planning and designing is a conserved traditional house, Infill Design conservation is employed as a technical method in the designing process. Infill Design conservation divides the traditional house into three zones i. e. critical, important, and contributory zone. The methods consist of issue and idea study, site determination, study of literature, problem statement formulation, approach analysis, macro, mezzo, and micro zone analysis, and the result of data analysis which is presented in the form of concept. The concept of macro scale includes the concept of circulation, transportation, and the role and position of the cultural center on the structure of Kotagede Cultural Heritage Site. The mezzo-scale concept includes the concept of zonesequence. In each sequence, some activities and places of performing art activities will be selected based on their Genius Loci. The micro scale concept includes Infill Design of spatiality, structure, and utility by concerning the form, color, and original material of the roof, walls and floor.
\end{abstract}

Keywords: Cultural Center, Infill Design, Genius Loci, Kotagede, Traditional House, Traditional Performing Art

\section{PENDAHULUAN}

Yogyakarta ditetapkan sebagai satu dari lima daerah istimewa di Indonesia karena kekayaan warisan budaya yang dimiliki. Sejak ditetapkan sebagai daerah istimewa, budaya menjadi arus utama pembangunan di segala bidang. Namun nyatanya, eksistensi budaya di Yogyakarta terus mengalami penurunan. Contoh warisan budaya yang menurun adalah kelompok seni pertunjukan tradisional.

Kotagede merupakan bekas ibukota kerajaan Jawa-Islam yang menjadi cikal bakal lahirnya Yogyakarta. Kotagede memiliki struktur kota lama Jawa-Islam yang disebut catur gatra tunggal, terdiri dari masjid, pasar, keraton dan alun-alun. Kotagede juga memiliki warisan rumah pusaka dan seni pertunjukan tradisional sebagai pembentuk jiwa dan identitas kawasan. Namun, warisan budaya tersebut juga terus mengalami kemunduran, antara lain akibat gempa bumi yang menimpa Yogyakarta tahun 2006, desakan kebutuhan ekonomi, pemenuhan kebutuhan ruang bagi kegiatan modern serta kurangnya pemahaman dan kepedulian masyarakat terhadap warisan budaya yang dimiliki.

Genius Loci merupakan kepercayaan bangsa Roma kuno bahwa setiap wujud memiliki kejeniusan yang menjadi jiwa pelindungnya. Genius Loci kemudian digunakan untuk memahami jiwa tempat. Menurut Norberg-Schulz (1984), jiwa tempat dimaknai sebagai "character of locality and 
living reality" atau karakter lokal dan realitas yang hidup setiap hari.

Masalah yang diselesaikan dalam olah desain rumah pusaka sebagai wadah kegiatan seni pertunjukan dengan pendekatan Genius Loci adalah masalah pemintakatan, pengolahan bentuk dan elemen bangunan rumah pusaka. Dalam skala kawasan, masalah yang diselesaikan adalah masalah sirkulasi, transportasi, pengolahan simpul dan penggal jalan.

Pusat Kebudayaan dengan pendekatan Genius Loci bertujuan untuk melestarikan, memanfaatkan dan mengembangkan warisan budaya di Kotagede. Upaya tersebut dilakukan untuk memperkokoh jiwa dan identias kawasan serta menjadi salah satu pilar pembentuk citra budaya bagi Daerah Istimewa Yogyakarta.

\section{METODE}

Penyusunan konsep perancangan dan perencanaan Pusat Kebudayaan di Kotagede dengan pendekatan Genius Loci dilakukan melalui metode:

1. Penelusuran gagasan melalui studi isu dan fenomena budaya di Yogyakarta.

2. Penentuan obyek dan lokasi dari hasil perumusan gagasan-gagasan awal.

3. Studi lapangan dengan mengunjungi dan merasakan langsung suasana ruang untuk: (a) mengetahui struktur dan fenomena kawasan terkait keberadaan situs catur gatra tunggal; (b) menentukan rumah pusaka yang akan dikembangkan; (c) menentukan ragam kegiatan seni pertunjukan yang akan diwadahi; dan (d) menentukan batasan desain kawasan serta kondisi sirkulasi dan transportasi kawasan terpilih.

4. Studi pustaka yang berkaitan dengan teori Genius Loci dan metode konservasi infill design melalui buku, piagam, rekomendasi hasil dari konferensi, peraturan, ketetapan perundangundangan, jurnal, skripsi, tesis dan disertasi dan artikel untuk merumuskan strategi desain.

5. Perumusan permasalahan dan persoalan yang akan diselesaikan dalam desain.

6. Analisis konsep perencanaan dan perancangan dengan pertimbangan tiga elemen utama yaitu: (a) Genius Loci sebagai pendekatan; (b) Pusat Kebudayaan sebagai obyek yang akan direncanakan dan dirancang; dan (c) Infill Design sebagai metode teknis.

7. Perumusan hasil analisis dalam bentuk konsep kegiatan, pelaku, peruangan, olah tapak dan tata massa, olah bentuk, olah elemen interior, utilitas, struktur dan material. Perumusan konsep sirkulasi, transportasi dan sekuen jalan sehingga mendapat kepaduan dan keselarasan dalam skala kawasan.

\section{ANALISIS}

\subsection{Analisis Pendekatan Genius Loci}

Analisis pendekatan Genius Loci merupakan analisis penerapan konsep Genius Loci pada desain Pusat Kebudayaan. Teori Infill Design membantu teknis pelaksanaan, mengingat obyek yang dipilih merupakan warisaan budaya yang dilindungi. Prinsip utama Infill Design menurut Awal (2011), adalah "menentukan zona pada situs atau komplek". Hubungan ketiga unsur tersebut dapat dilihat pada Gambar 1. Hubungan ketiga elemen tersebut digunakan sebagai dasar dalam analisis pendekatan konsep Genius Loci seperti tampak pada Lampiran 1.

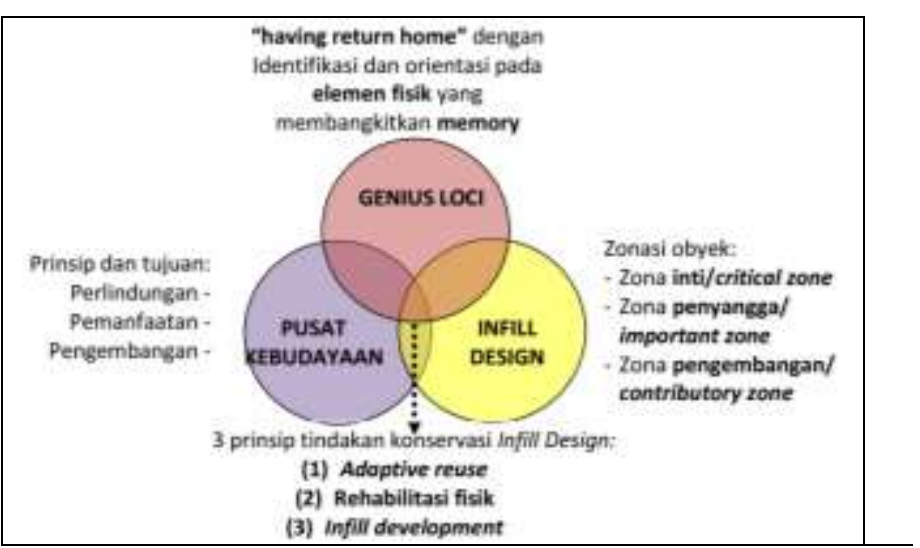

Gambar 1. Hubungan Teori Genius Loci, Infill Design dan Pusat Kebudayaan.

Tabel 1. Perbandingan Jalur Utama KCB Kotagede

\begin{tabular}{|ccccc|}
\hline $\begin{array}{c}\text { Nama } \\
\text { Jalan }\end{array}$ & \multicolumn{2}{l}{$\begin{array}{l}\text { Budaya, Akses, } \\
\text { Sejarah Fasilitas }\end{array}$} & $\begin{array}{c}\text { keruntu- } \\
\text { kan }\end{array}$ & $\begin{array}{c}\text { Zonasi } \\
\text { Pelesta } \\
\text { rian }\end{array}$ \\
\hline $\begin{array}{c}\text { Jalan } \\
\text { Mondo- }\end{array}$ & $* * * *$ & $* * *$ & $\begin{array}{c}\text { Jasa dan } \\
\text { dagang }\end{array}$ & $\begin{array}{c}\text { Budaya } \\
\text { keraky }\end{array}$ \\
\hline
\end{tabular}




\begin{tabular}{|c|c|c|c|c|}
\hline rakan & & & & atan \\
\hline $\begin{array}{l}\text { Jalan Selo } \\
\text { Gilang }\end{array}$ & $* * * *$ & $* *$ & Heritage & $\begin{array}{l}\text { Monu } \\
\text { men \& } \\
\text { situs }\end{array}$ \\
\hline $\begin{array}{c}\text { Jalan } \\
\text { Karang Lo }\end{array}$ & ** & $* *$ & $\begin{array}{r}\text { Jasa dan } \\
\text { dagang }\end{array}$ & $\begin{array}{c}\text { Budaya } \\
\text { keraky } \\
\text { atan }\end{array}$ \\
\hline $\begin{array}{c}\text { Jalan } \\
\text { Kemasan }\end{array}$ & ** & $* * *$ & $\begin{array}{c}\text { Jasa dan } \\
\text { dagang }\end{array}$ & $\begin{array}{c}\text { Budaya } \\
\text { keraky } \\
\text { atan }\end{array}$ \\
\hline
\end{tabular}

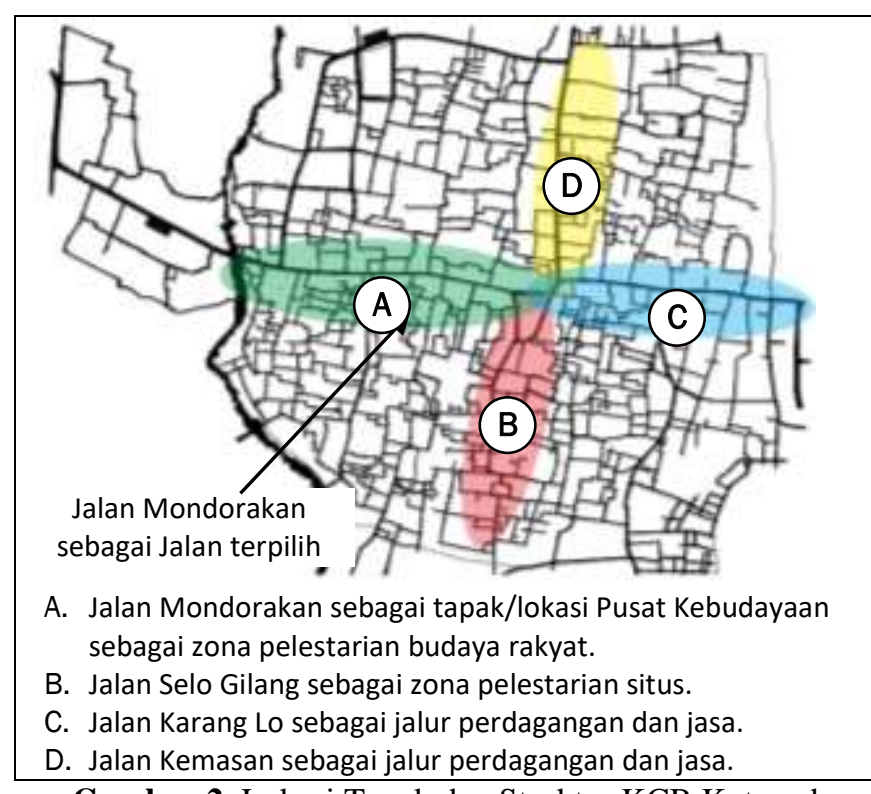

Gambar 2. Lokasi Tapak dan Struktur KCB Kotagede.

\subsection{Analisis Pemilihan Tapak (Makro)}

Kawasan Cagar Budaya Kotagede memiliki empat jalan utama yaitu Jalan Selo Gilang, Jalan Mondorakan, Jalan Kemasan dan Jalan Karang Lo. Jalan Mondorakan dipilih sebagai jalur utama Pusat Kebudayaan berdasarkan perbandingan yang ditunjukan oleh Tabel 1. Struktur kawasan Menjadi seperti ditunjukkan pada Gambar 2.

\subsection{Analisis Pengolahan Tapak (Mezzo) 3.3.1 Analisis Simpul Jalan}

Simpul pada Jalan Mondorakan terbagi menjadi dua, yaitu simpul jalan dengan jalan dan simpul jalan dengan gang yang menghubungkan dengan potensi tertentu di dalam gang atau kampung. Simpul jalan terpilih ditunjukkan oleh Gambar 3.

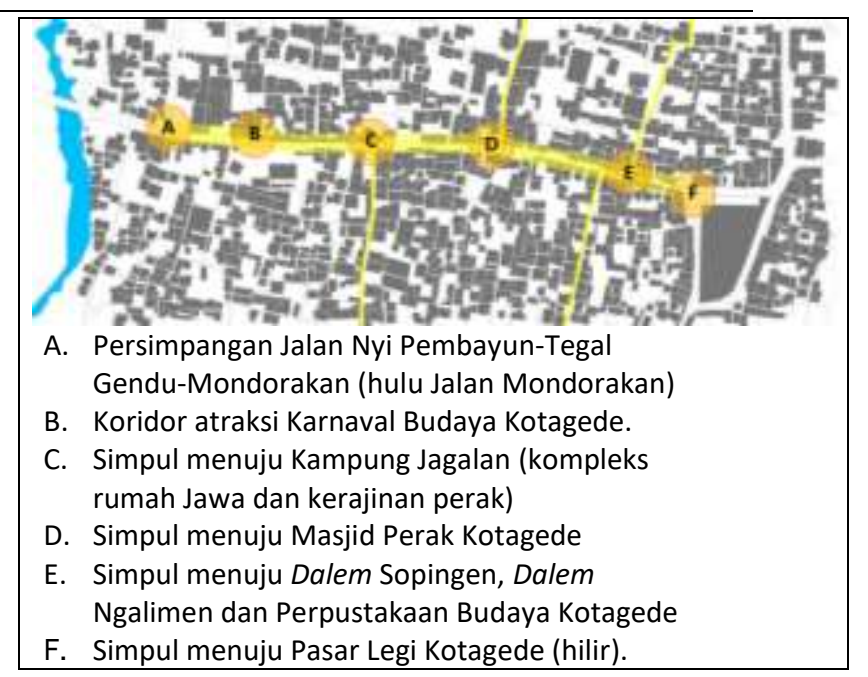

Gambar 3. Simpul Penting pada Jalan Mondorakan.

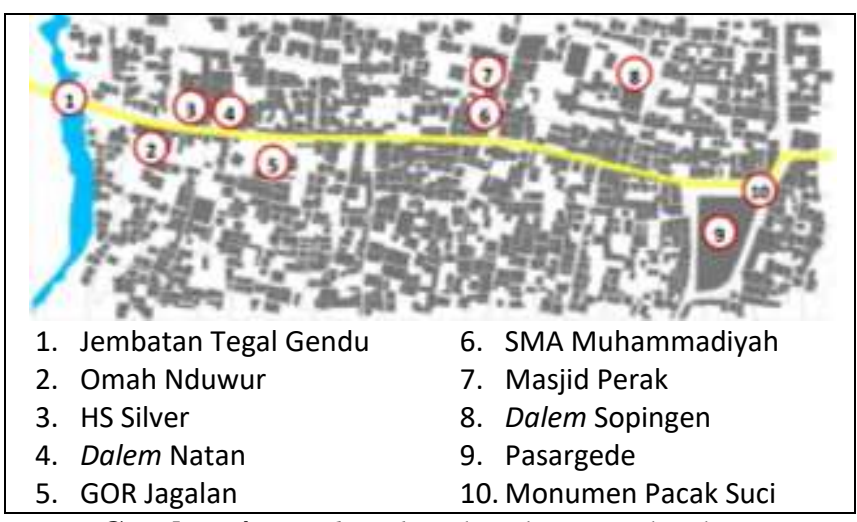

Gambar 4. Landmark pada Jalan Mondorakan.

\subsubsection{Analisis Landmark}

Analisis landmark pada tapak bertujuan memperkuat identitas kawasan untuk membantu orientasi dan identifikasi yang merupakan proses seseorang dalam memahami Genius Loci suatu kawasan. Analisis landmark dilakukan melalui studi lapangan dan menghasilkan peta landmark seperti pada Gambar 4.

\subsubsection{Analisis Gaya Bangunan}

Gaya bangunan yang terdapat pada Jalan Mondorakan antara lain Rumah Kalang, bangunan modern, bangunan bercorak Islam, dan Rumah Jawa yang memiliki toko (dapat dilihat pada Gambar 5). Analisis gaya bangunan akan digunakan untuk proses analisis sekuen kawasan Pusat Kebudayaan. 


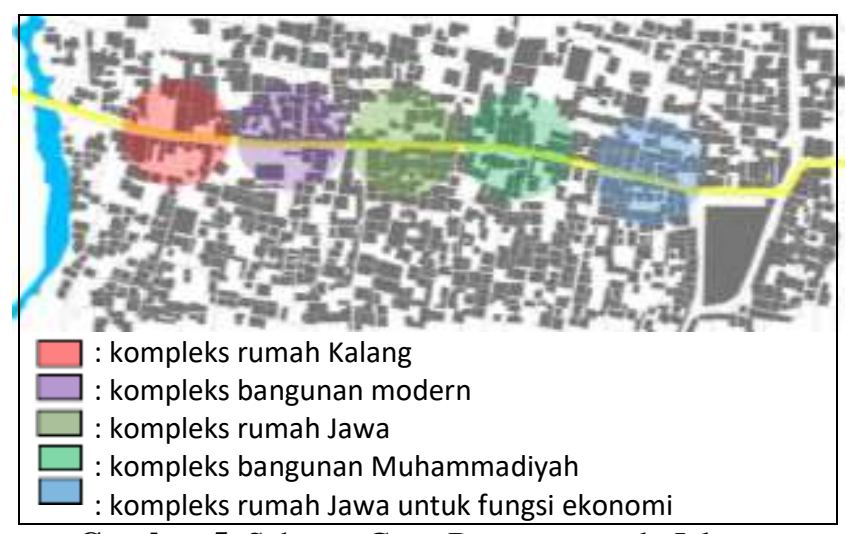

Gambar 5. Sebaran Gaya Bangunan pada Jalan Mondorakan.

Tabel 2. Kriteria Pemilihan Rumah Pusaka.

\begin{tabular}{|cccccc|}
\hline Kriteria: & 1 & 2 & 3 & 4 & 5 \\
\hline Kesenian & $\sqrt{ }$ & $\sqrt{ }$ & $\sqrt{ }$ & - & $\sqrt{ }$ \\
Karakter & $\sqrt{ }$ & $\sqrt{ }$ & $\sqrt{ }$ & $\sqrt{ }$ & $\sqrt{ }$ \\
Tata ruang & $\sqrt{ }$ & $\sqrt{ }$ & $\sqrt{ }$ & $\sqrt{ }$ & $\sqrt{ }$ \\
\hline
\end{tabular}

\subsubsection{Analisis Sekuen Ruang Jalan}

Jalan Mondorakan sebagai jalur utama Pusat Kebudayaan dibagi menjadi 3, pembagian tersebut dapat dilihat pada Gambar 6.

\subsection{Analisis Rumah Pusaka (Mikro) 3.4.1 Analisis Pemilihan Rumah Pusaka}

Rumah yang akan dijadikan sebagai wadah kegiatan seni pertunjukan tersebar di sepanjang Jalan Mondorakan. Beberapa rumah berada di dalam gang. Kriteria yang digunakan dalam pemilihan rumah tersebut yaitu:

1. Memiliki potensi kegiatan seni pertunjukan untuk dilestarikan.

2. Memiliki karakter rumah pusaka kotagede melalui bentuk, warna dan material pada dinding, lantai dan atap.

3. Memiliki tata ruang rumah pusaka kotagede untuk dimanfaatkan sebagai wadah kegiatan Pusat Kebudayaan.

Berdasarkan analisis yang dilakukan, terpilih lima rumah dengan pertimbangan pemilihan seperti ditunjukkan pada Tabel 2 .

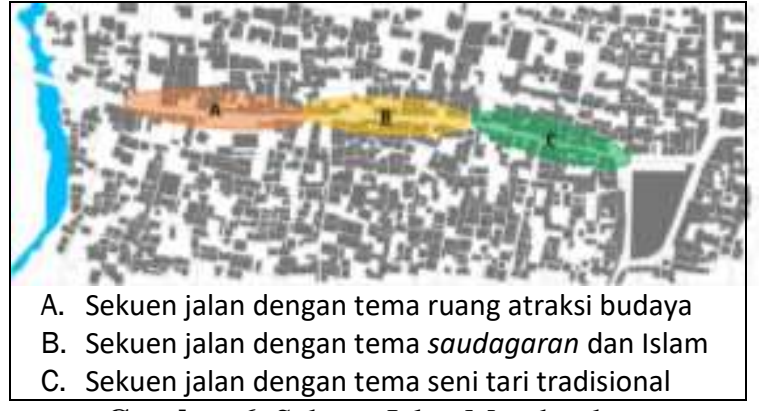

Gambar 6. Sekuen Jalan Mondorakan.

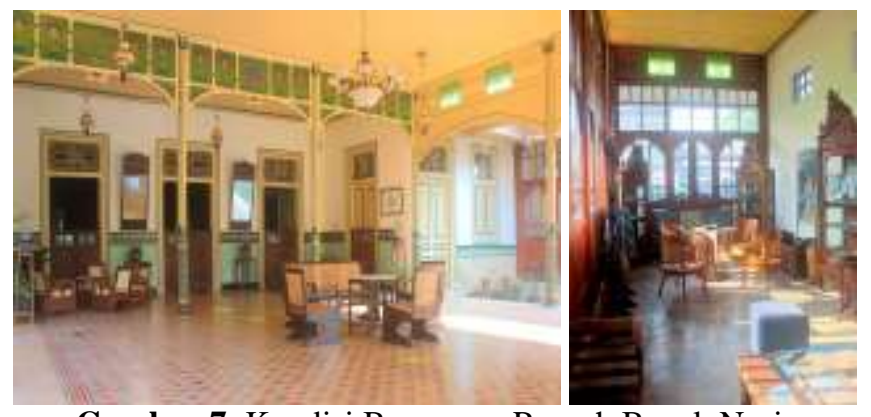

Gambar 7. Kondisi Bangunan Rumah Bapak Nasir

\subsubsection{Analisis 1: Rumah Bapak Nasir}

1. Analisis Tata Ruang

Zonasi rumah Bapak Nasir, terbagi menjadi: zona inti terdiri dari pendapa, dalem dan senthong; zona penyangga terdiri dari mburi omah, gadri dan gandhok; dan zona pengembangan terdiri dari halaman depan dan tengah yang menurut aturan harus dipertahankan sebagai RTH. Analisis tata ruang rumah Bapak Nasir pada Lampiran 3.

2. Analisis Fisik Bangunan

Rumah termasuk golongan Rumah Kalang dengan elemen dan ornamentasi bangunan menggabungkan Arsitektur Art Nouveau dan Islam. Rumah juga disebut sebagai Kraton Alit oleh masyarakat, karena keindahan ornamentasi dan ukurannya yang luas, dapat dilihat pada Gambar 7.

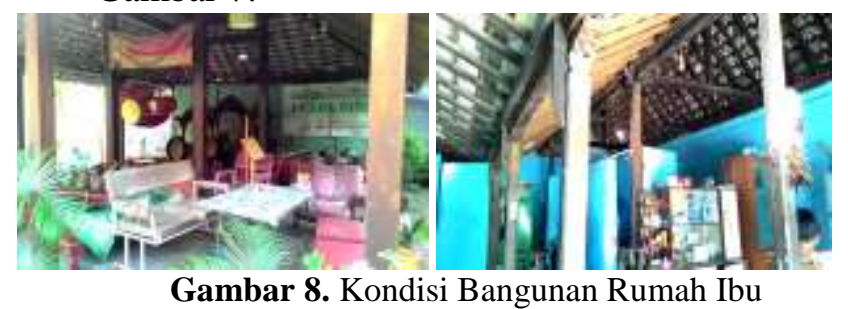
Nunuk

3. Analisis Kegiatan 
Kegiatan yang diwadahi adalah seni, galeri, cafe dan guestroom. Orientasi kegiatan ke dalam, namun tetap menghidupi lingkungan. Pagar rumah rendah menghilangkan kesan inklusif.

\subsubsection{Analisis 2: Rumah Ibu Nunuk}

1. Analisis Tata Ruang

Zonasi rumah Ibu Nunuk, terbagi menjadi: zona inti yaitu pendapa, dalem dan senthong; zona penyangga yaitu gadri; dan zona pengembangan yaitu toko, kamar dan kamar mandi. Analisis pada Lampiran 2.

2. Analisis Fisik Bangunan

Rumah termasuk Rumah Jawa yang berada di dalam gang. Dahulu rumah berada dalam satu komplek jalan rukunan, sehingga rumah cenderung tertutup (berpagar) dari gang, dapat dilihat pada Gambar 8. Rumah mengalami banyak pergeseran dinding paska gempa 2006. Rehabilitasi dilakukan dengan menggeser dan memberi perkuatan dinding lama.

3. Analisis Kegiatan

Pada tahun 1960-an, rumah digunakan sebagai wadah kesenian keroncong. Saat ini, terdapat dua kelompok karawitan yang rutin berlatih yaitu Kelompok Karawitan Puspa Rini (sejak tahun 1985) dan Kelompok Ngesti Wiromo (sejak tahun 1983).

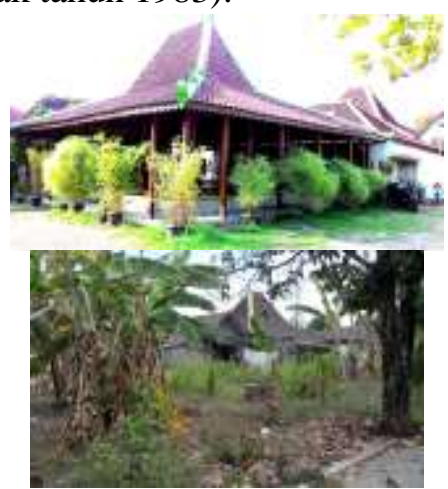

Gambar 9. Kondisi Bangunan Rumah Bapak Suprapto

\subsubsection{Analisis 3: Rumah Bapak Suprapto}

1. Analisis Tata Ruang
Zonasi rumah Bapak Suprapto, terbagi menjadi: zona inti yang terdiri dari pendapa, dalem dan senthong; zona penyangga yang terdiri dari gadri dan gandhok; dan zona pengembangan yang terdiri dari halaman depan dan belakang. Analisis tata ruang rumah Bapak Suprapto dapat dilihat pada Lampiran 4.

2. Analisis Fisik Bangunan

Rumah termasuk Rumah Jawa. Rumah memiliki ukuran lebih luas dari rumah di sekitarnya karena dahulu dimiliki oleh Raden Amat Dalem Sopingi sebagai juru kunci makam Kotagede. Pendapa saat ini adalah pendapa baru. Gandhok kiwa masih dalam kondisi hancur. Bekas gandhok tengen dibangun bangunan baru. Dalem tidak difungsikan karena lantai, plafon dan dinding yang rusak paska gempa bumi, krumah dapat dilihat pada Gambar 9.

3. Analisis Kegiatan

Rumah digunakan untuk kegiatan sosial-budaya oleh masyarakat, komunitas dan akademisi, contoh untuk kegiatan pelatihan, workshop dan diskusi serta kegiatan kesenian seperti keroncong, kethoprak dan pergelaran seni tari. Pada sekitar tahun 1950, rumah digunakan sebagai sanggar berbagai kesenian.
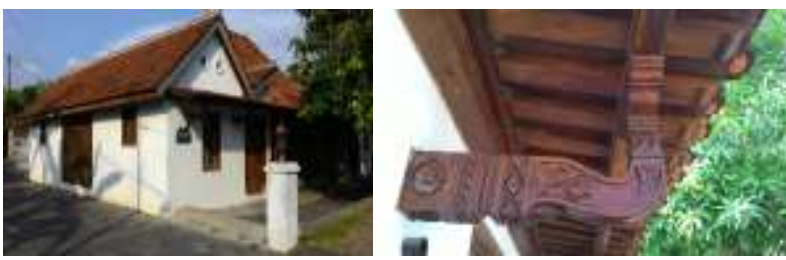

Gambar 10. Kondisi Bangunan Rumah Bapak Sutejo.

\subsubsection{Analisis 4: Rumah Bapak Sutejo}

1. Analisis Tata Ruang

Zonasi rumah Bapak Sutejo, terbagi menjadi: zona inti terdiri dari dalem dan senthong; zona penyangga terdiri dari gandhok; dan zona pengembangan terdiri dari omah mburi dan halaman depan. Analisis tata ruang rumah Bapak Suprapto dapat dilihat pada Lampiran 5. 
2. Analisis Fisik Bangunan

Rumah merupakan golongan Rumah Limasan Kotagede. Rumah tidak memiliki pendapa. Dalem dan gandhok rumah masih memiliki struktur dinding asli. Atap rumah mengalami perbaikan paska gempa bumi 2006. Area belakang rumah hancur. Lantai aci rumah dalam kondisi retak dan pecah. Rumah memiliki karakter fisik berupa bahu dhanyang dan gebyok kayu. Kondisi fisik rumah dapat dilihat pada Gambar 10

3. Analisis Kegiatan

Paska rehabilitasi paska gempa tahun 2006, rumah dijadikan ruang publik kegiatan budaya. Namun belum ada agenda rutin kegiatan budaya, sehingga rumah terbengkalai. Pemilik rumah sudah tidak menjadikan rumah ini sebagai rumah pokok. Perawatan dan pemanfaatan diserahkan kepada publik.
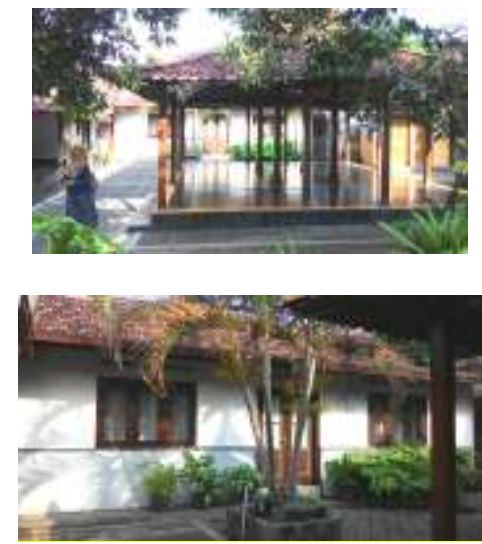

Gambar 11. Kondisi Bangunan Rumah Bapak Ngalim.

\subsubsection{Analisis 5: Rumah Bapak Ngalim}

1. Analisis Tata Ruang

Zonasi rumah Bapak Ngalim, terbagi menjadi: zona inti yaitu pendapa, dalem dan senthong; zona penyangga yaitu gandhok; dan zona pengembangan yaitu omah mburi dan halaman depan. Analisis tata ruang rumah dapat dilihat pada Lampiran 6.

2. Analisis Fisik Bangunan

Rumah termasuk golongan Rumah Jawa Kotagede. Pendapa masih merupakan pendapa asli dengan kondisi struktur stabil, tidak retak dan pecah. Rumah telah memiliki struktur penguat berupa kolom beton berukuran $20 \times 30$ $\mathrm{cm}$ dan $20 \times 20 \mathrm{~cm}$ pada gandhok sebagai respon dari gempa yang menimpa tahun 2006. Konsol rumah memiliki material, warna dan bentuk dengan gaya Eropa, dapat dilihat pada Gambar 11.

3. Analisis Kegiatan

Pendapa rumah dijadikan sebagai ruang publik untuk kegiatan workshop budaya, pertemuan warga dan acara sosial-keagamaan lainnya. Setiap hari pukul 15.00-18.00 WIB, pendapa digunakan untuk latihan oleh Sanggar Seni Tari Sekar Mayang.

\section{KESIMPULAN (KONSEP DESAIN)}

Konsep desain menitikberatkan pada pembentukan genius loci kawasan dan rumah pusaka melalui pengolahan elemen fisik dengan teknis konservasi infill design. Konsep desain yang dihasilkan yaitu:

1. Pada skala makro, Pusat Kebudayaan berperan sebagai wadah pelestarian budaya kerakyatan yang pendukung dan mengantarkan pengunjung menuju situs catur gatra tunggal sebagai inti Kawasan Cagar Budaya Kotagede.

2. Pada skala mezzo, Jalan Mondorakan dipilih sebagai jalur utama untuk menghubungkan wadah-wadah seni pertunjukan pada Pusat Kebudayaan. Jalan Mondorakan dibagi menjadi tiga sekuen sesuai karakter bangunan dan potensi seni pertunjukan yang dimiliki setiap sekuen. Ruang publik dan koridor jalan diolah sebagai ruang kegiatan sosial dan budaya masyarakat, ditunjukkan oleh Gambar 12 dan 13. Pengolahan simpul dilakukan untuk mengarahkan menuju lokasi penting di dalam gang atau kampung, pengolahan simpul ditunjukan oleh Gambar 14.

3. Pada skala mikro, rumah pusaka dilestarikan, dimanfaatkan dan 
dikembangkan sebagai wadah seni pertunjukan. Setiap rumah memiliki konsep tertentu sesuai dengan potensi ruang, fisik bangunan dan kegiatan yang dimiliki. Konsep rumah-rumah tersebut adalah sebagai berikut:

1. Rumah Bapak Nasir sebagai wadah pentas seni pertunjukan dan galeri dokumentasi.

2. Rumah Ibu Nunuk sebagai sanggar seni karawitan.

3. Rumah Bapak Suprapto sebagai wadah pentas seni pertunjukan dan ruang komunitas seni pertunjukan.

4. Rumah Bapak Sutejo sebagai perpustakaan budaya Kotagede.

5. Rumah Bapak Ngalim sebagai sanggar seni tari tradisional.

Konsekuensi dari fungsi baru rumah sebagai ruang publik dan wadah kegiatan seni adalah antara lain:

1. Adaptive reuse ruang eksisting untuk fungsi baru dengan penambahan elemen interior, ditunjukkan oleh Gambar 15.

2. Rehabilitasi fisik ruang atau bangunan yang hancur/runtuh.

3. Infill development lahan bebas.

4. Olah struktur untuk membentuk ruang baru pada bangunan lama. ditunjukkan oleh Gambar 16.

5. Olah struktur untuk menunjang utilitas ruang dengan fungsi baru, ditunjukkan oleh Gambar 17.

6. Olah pencahayaan, penghawaan dan akustik ruang untuk menunjang fungsi baru dengan meminimalisasi kerusakan pada bangunan lama, ditunjukkan oleh Gambar 18.

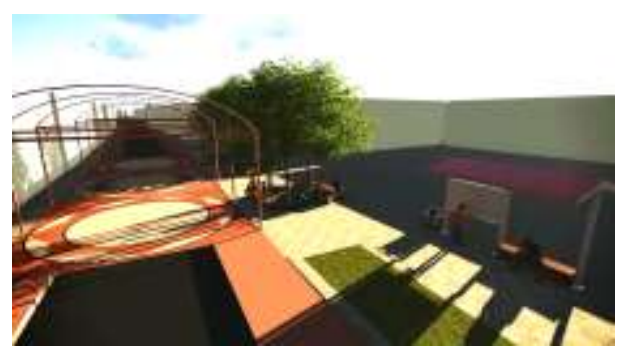

Gambar 12. Koridor Jalan sebagai Ruang Atraksi Karnaval Budaya.

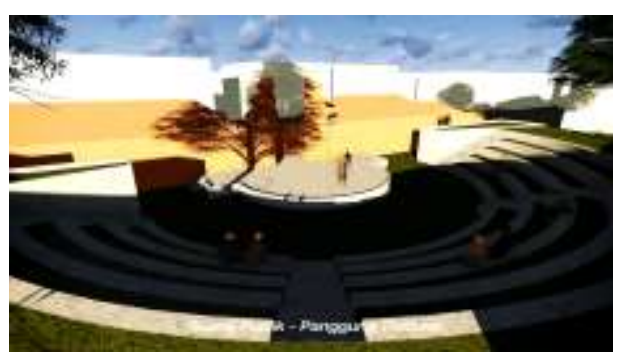

Gambar 13. Ruang Publik sebagai Ruang Interaksi Sosiai-Budaya

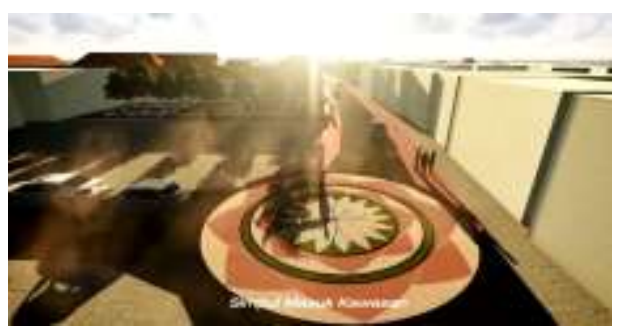

Gambar 14. Pengolahan Simpul Jalan

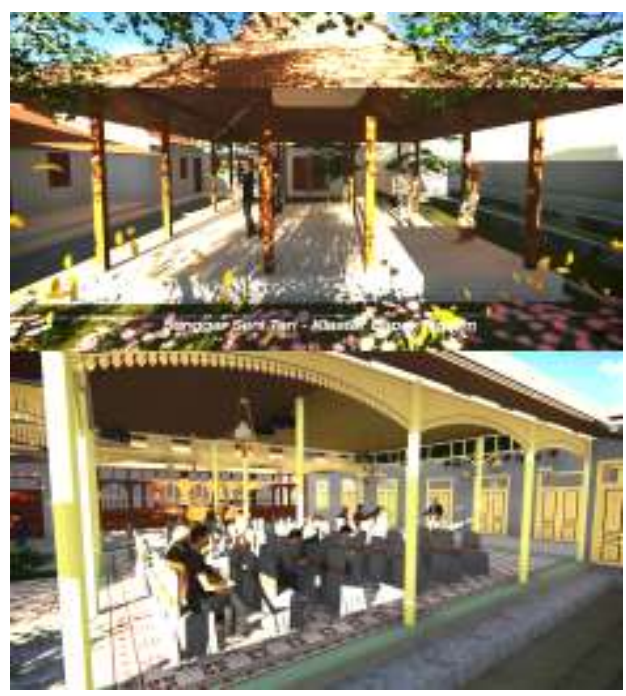

Gambar 15. Adaptive Reuse Pendapa sebagai Ruang Pergelaran dan Latihan.

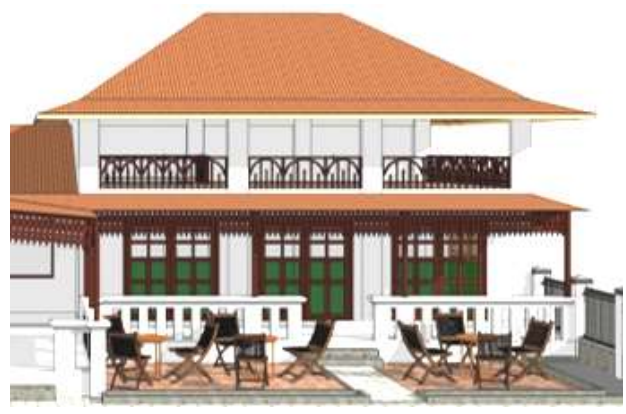

Gambar 16. Olah Struktur untuk

Membentuk Ruang Baru pada Lantai 2 


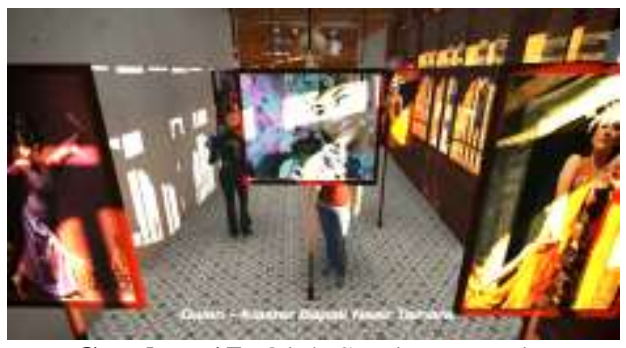

Gambar 17. Olah Struktur untuk Menunjang Utilitas Ruang.

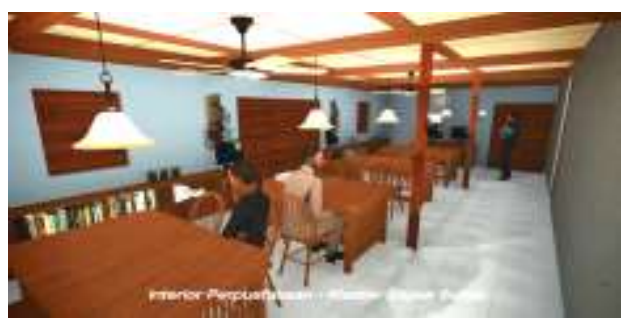

Gambar 18. Olah Pencahayaan dan Penghawaan Ruang Baca Perpustakaan.

\section{REFERENSI}

Norberg-Schulz, Christian, 1984, Genius Loci: Towards Phenomenology of Architecture, New York. Rizolly International Publication

Awal, Han, 2011, Pengantar Panduan Konservasi Bangunan Bersejarah Masa Kolonial, Jakarta. Pusat Dokumentasi Arsitektur. 
Rud Yoneko Tunggadewi, Hardiyati, Kusumaningdyah Nurul H., Pusat Kebudayaan sebagai ...

\section{LAMPIRAN}

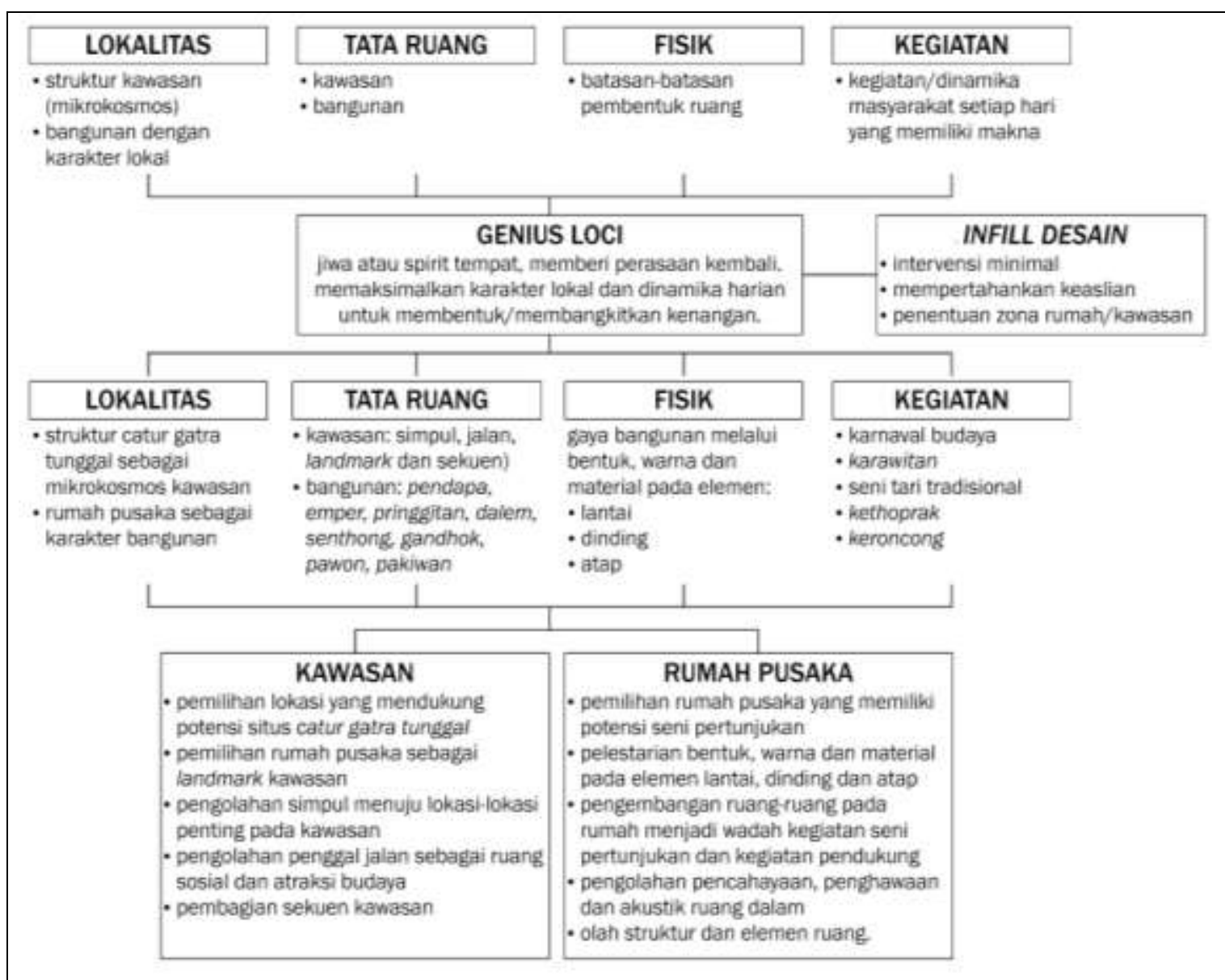

Lampiran 1. Pendekatan Konsep Genius Loci.

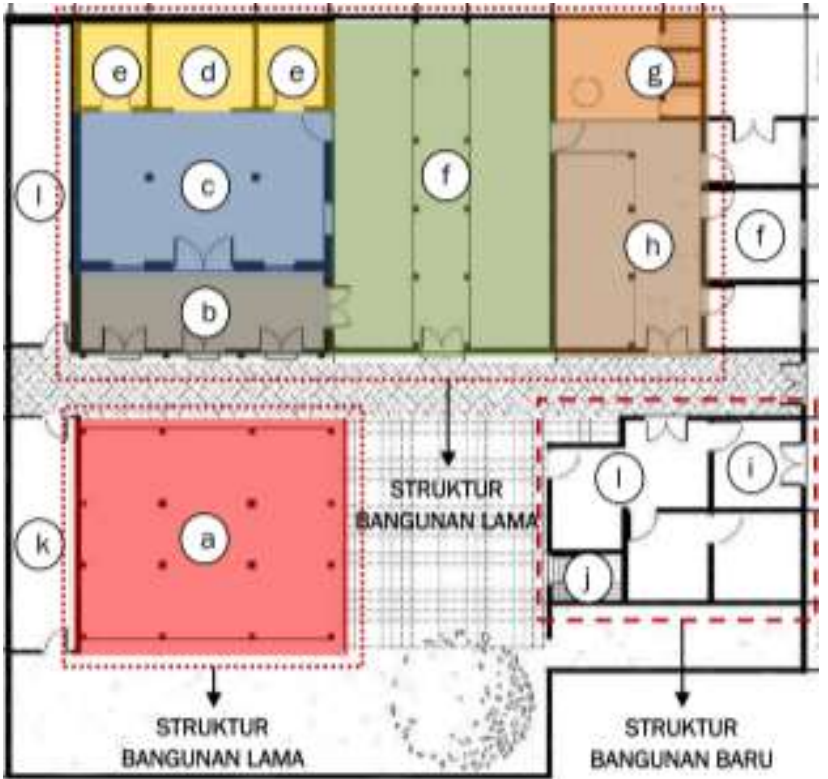

Keterangan Tata Ruang Rumah Jawa:

Pendapa

Emper

Dalem

Senthong

Gadri

Pawon

Pakiwan

Keterangan Fungsi Ruang Saat Ini:

a. Ruang latihan gamelan

b. Ruang penyimpanan gamelan

c. Ruang kosong

d. Mushalla

e. Gudang/kosong

f. Ruang keluarga dan kamar

g. Kamar mandi dan cuci

h. Dapur dan garasi

b. Warung makanan ringan

1. Kamar mandi tamu

k. Gudang alat

L. Ruang kosong

Lampiran 2. Analisis Tata Ruang Rumah Ibu Nunuk 


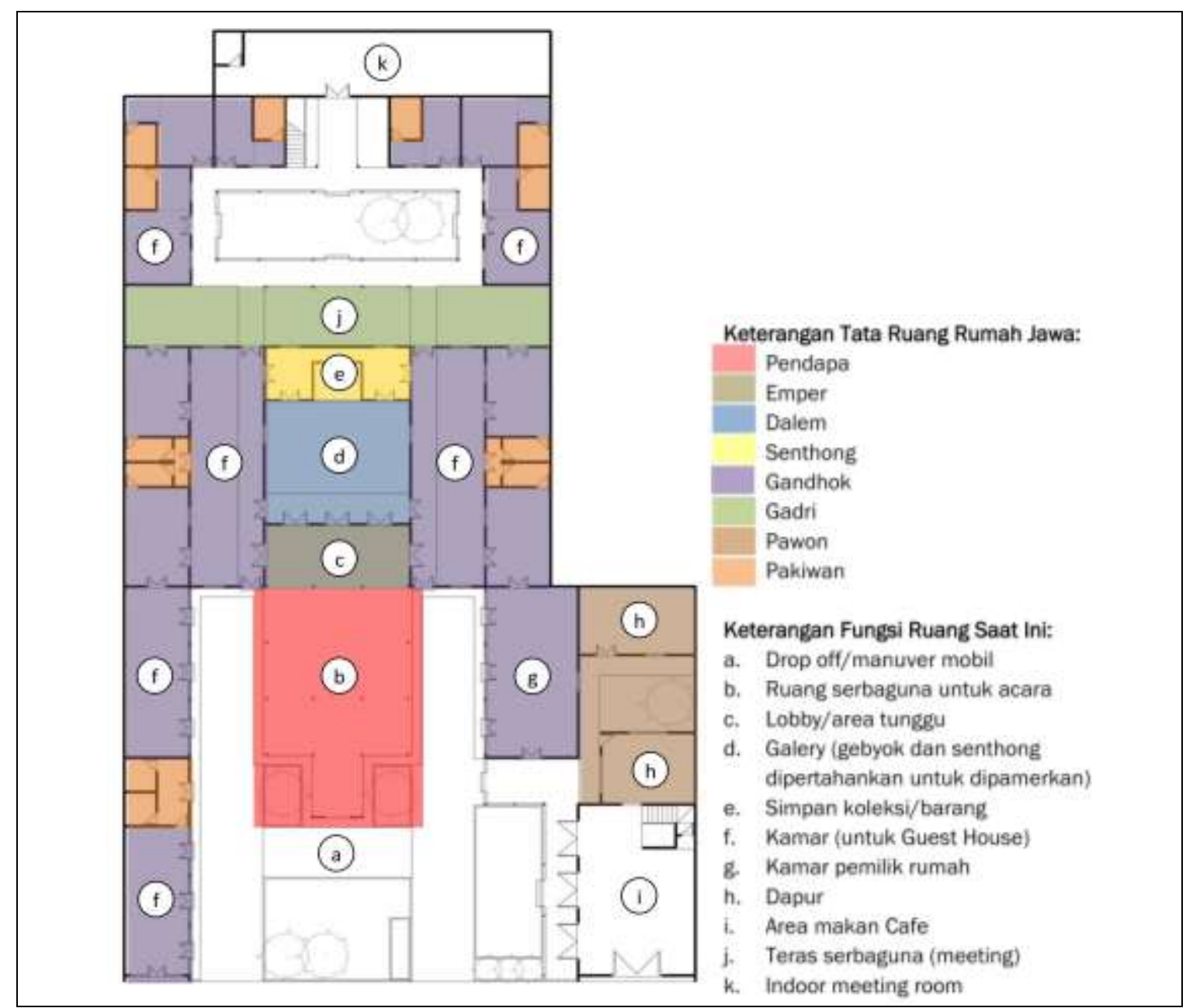

Lampiran 3. Analisis Tata Ruang Rumah Bapak Nasir Tamara

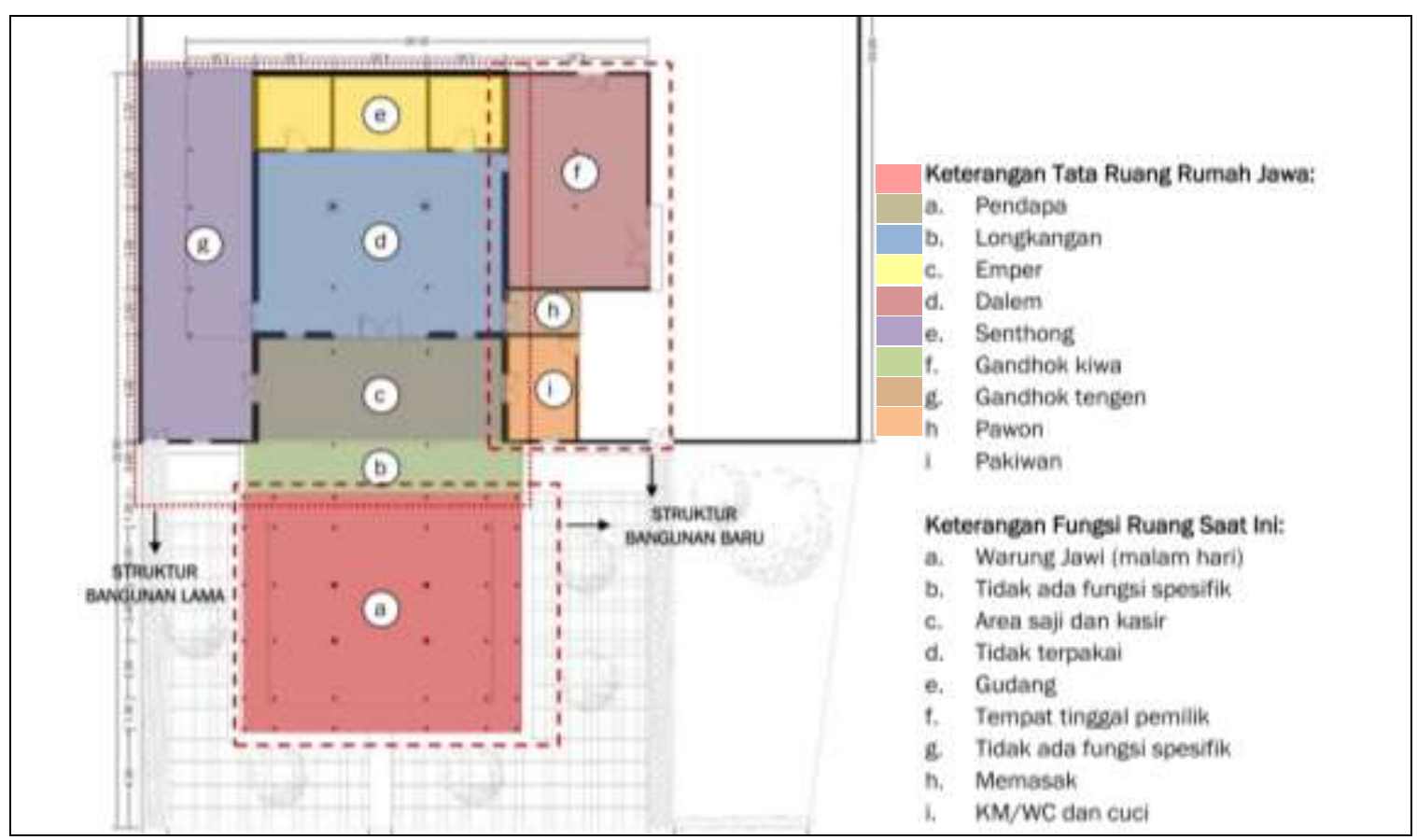

Lampiran 4. Analisis Tata Ruang Rumah Bapak Suprapto 
Rud Yoneko Tunggadewi, Hardiyati, Kusumaningdyah Nurul H., Pusat Kebudayaan sebagai ...

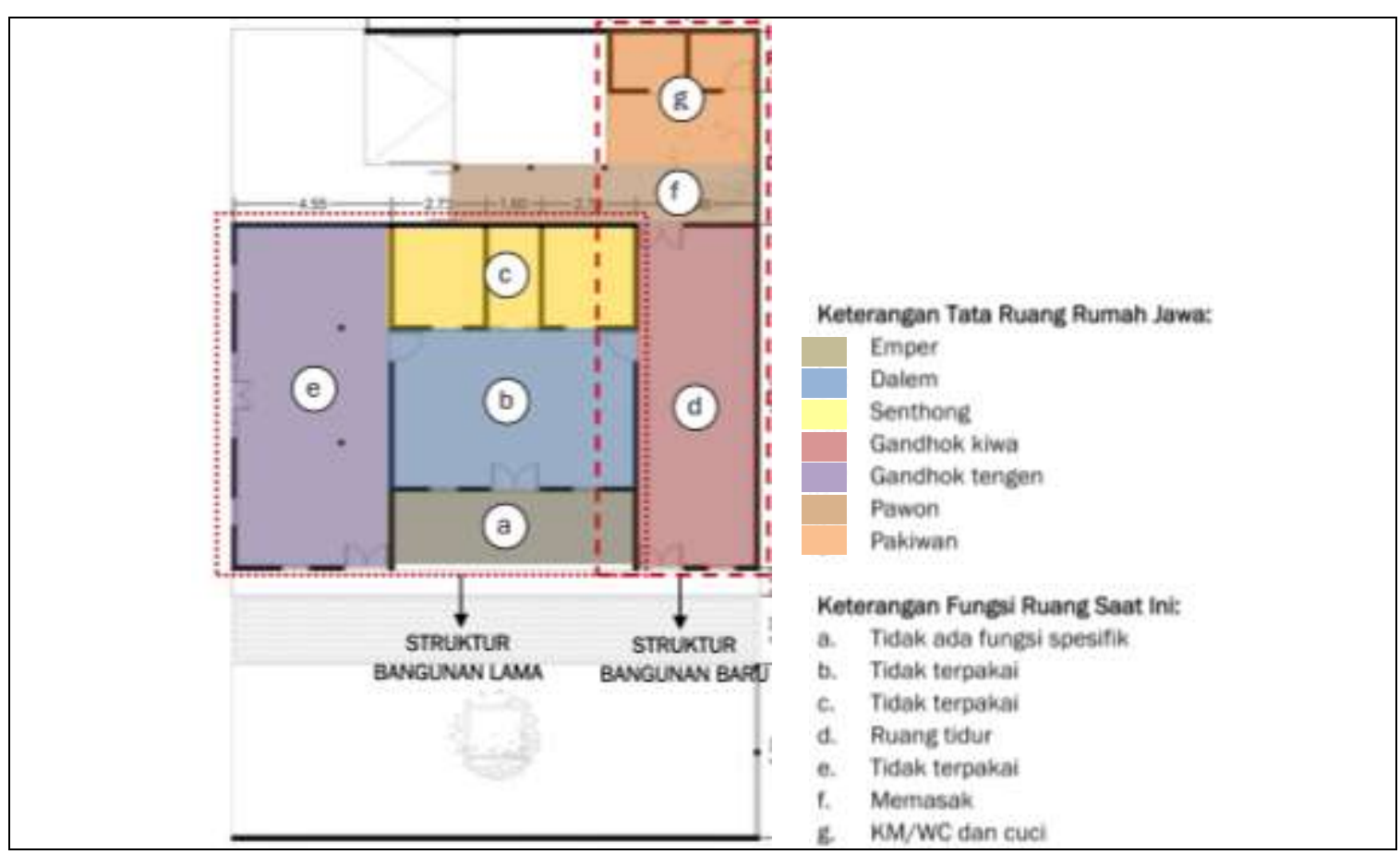

Lampiran 5. Analisis Tata Ruang Rumah Bapak Sutejo

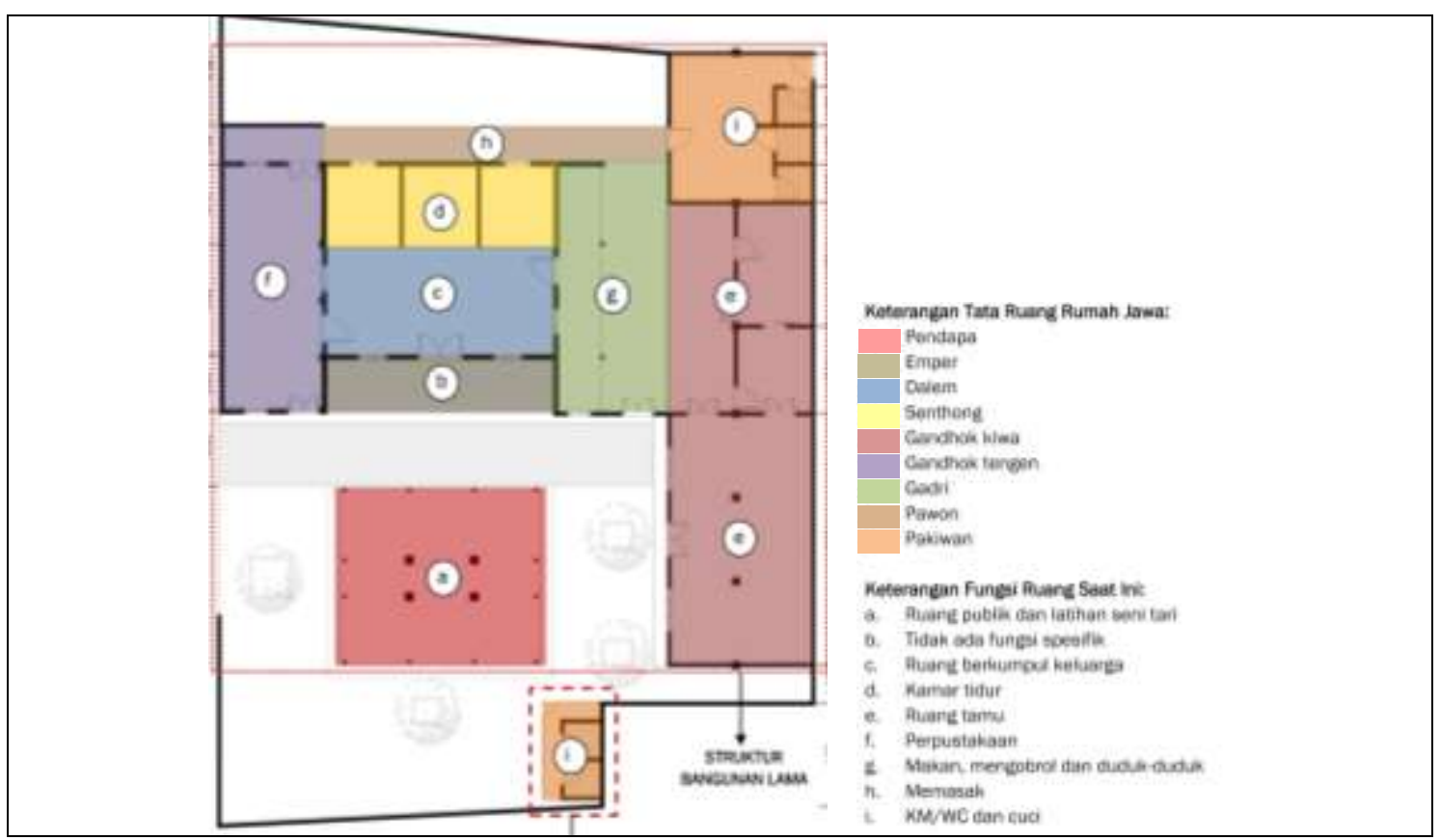

Lampiran 6. Analisis Tata Ruang Rumah Bapak Ngalim 